\title{
A Further Study of Financing Support Ways of Small and Medium-sized Enterprises
}

\author{
Hou Dongmei ${ }^{1}$, Huang Qian ${ }^{2}$ \\ ${ }^{1}$ Economics and Management Department Yibin University, Yibin, Sichuan,China, 644007 \\ ${ }^{2}$ Yibin Cuiping Tanghu Foreign Language School, Yibin, Sichuan, China, 644000 \\ 36159945@qq.com
}

\begin{abstract}
Small and medium-sized enterprises plays a very important role in the process of China's economic development, which are emphasis of China's strategy for developing economy. But their financing difficulty has been the most prominent problem which hinders the healthy development of China's small and medium-sized enterprises. This paper begins with the existing significance of small and medium-sized enterprises to find out the underlying reasons of financing difficulty and now therefore proposes the corresponding countermeasures: 1. to perfect financing guarantee system of small and medium-sized enterprises, 2. to support from policy, 3. to strive to develop small and medium-size financial institution and so on.

Index Terms- small and medium-sized enterprises, financing, countermeasures
\end{abstract}

\section{Introduction}

At present, the value of the final products and service which the national small and medium-sized enterprises have created takes up about $60 \%$ of the national GDP. The commodities they have produced take up $60 \%$ of social total sales. The tax revenue they have turned over has exceeded half of the national tax revenue. They have provided about $80 \%$ of the jobs in cities and towns of the country. More than $75 \%$ of the independently innovative products and more than $80 \%$ of the patents of the country are invented by them. Small and medium-sized enterprises play an important role in the promotion of economic development, the increase of the government public finance income, social employment, economical restructure, and the course of the industrialization and urbanization, which are an important part of China's national economy.

In recent years, financing problems have been the prominent bottleneck of the development of privately-owned small and medium enterprises. The exploration of the solutions to the small and medium-sized enterprises financing problems of Government, financing institutions and researchers makes significant achievements whether in direct financing or in indirect financing and broad small and medium-sized enterprises also has obtained long-term development. As it is, small and medium-sized enterprises still are faced with financing constraints in their process of development, such as insufficient government support, incomplete credit guarantee system, and international market development fund shortage and so on. Therefore, how to help these small and mediumsized enterprises to do better and go further is the project we have been committed to solve. The easy choice is to expand financing support ways of small and medium-sized enterprises.

\section{II - Financing constraints of small and medium-sized enterprises}

A. The credit guarantee system of small and medium-sized enterprises needs to be perfected.

The credit guarantee system is a financial support system the countries of the world universally adopt to solve the financing question of small and medium-sized enterprises now. There are some data implying that at the end of 2002, there are more than 800 domestic guarantee agencies. But by 2004, this number has reached about 4000 . And there are other data from the various provinces and cities implying that by the end of 2006, there are 63 guarantee agencies in Beijing, of which the registered capital reaches 14.262 billion yuan; there are 122 guarantee agencies in Wenzhou, 73 of which was registered and incorporated in 2006.

Guarantee industry plays a positive role in the solution to the financing difficulty of small and medium-sized enterprises, but there are a lot of problems in the small and medium-sized enterprises credit guarantee practice in China: the government's worrying about shouldering new financial burden, who only acts as a guide without enough understanding and support, the mismatching credit guarantee institutions for small and medium-sized enterprises and status of financial institutions, lack of industry criterion and professional talents, illegal activities of private deposit and loan business and capitalization in disguised form, nonstandard operation of credit guarantee institutions for small and medium-sized enterprises and so on. These problems restrict the full play of guarantee and seriously threaten the sustainable development of guarantee organizations themselves, which are the stumbling blocks of the healthy development of guarantee industry. Therefore, it is quite necessary to specially perfect the credit guarantee system for the small and medium-sized enterprises and support and promote the development of the small and medium-sized enterprises.

\section{B. The phenomenon of "Loan Stint" still prevails among government-owned commercial banks}

By the end of June 2007, small enterprises credit number of the five large banks, ICBC, ABC, BOC, CCB and Bank of Communications is 5.359 million accounts, which is 13900 accounts more than that at the beginning of the year; total loan of small enterprises is 1512.551 billion yuan, which is 118.895 
billion yuan more than that at the beginning of the year, and the amplification is $8.53 \%$; non-performing loan proportion of small enterprises is $2.13 \%$ lower than that at the beginning of the year. Data from the banks shows that the loan situation of small enterprises begins to improve, but there are still some questions in its market improvement.

According to Hou Yunchun, vice director of State Council Research Office, $80 \%$ of small and medium-sized enterprises in China depend on equity capital to start and expand, more than $90 \%$ original capital of which originates from their primary owners, co-sponsors and families; only $29 \%$ of small and medium-sized enterprises got guaranteed loans in the first five years, which only takes up $1 \%$ of the total loan of the banks. The loan volume of small and medium-sized enterprises is generally low, and their unit cost of the loan is high; the problems of "adverse selection" and "moral hazard" caused by information asymmetry of credit market still exist; small and medium-sized enterprises often lack credit history, and it is hard for the banks to examine their credit status; many small and medium-sized enterprises don't have enough fixed capital or inventory for mortgage, so banks are relatively careful about the loan of small and medium-sized enterprises.

\section{The support of government is not enough.}

There are no special government organizations, such as training centers and centers for entrepreneurship supporting the development of small and medium-sized enterprises. In the numerous financing channels of small and medium-sized enterprises, the policies and measures of government are not perfect enough. As the macro regulator of national economy, the government has an inescapable responsibility on solving the financing problems of small and medium-sized enterprises. However, to definitude the principles and scale of government intervention and to expand the support from the government are where the stress falls.

\section{The difficulties in financing seriously restrict the road of} internationalization operation and development of small and medium-sized enterprises.

For years, China's small and medium-sized enterprises have achieved outstanding business performance with their unique advantages and produced many enviable cases with rapid development, which occupy important shares in many development indicators of the nation's various industries with certain international competitiveness and advantages. But as small and medium-sized enterprises have real advantages in international operation, further promotion of the international competitiveness of them is seriously restricted by many factors, such as the difficulties in financing and so on. Only by relying on the stronger financing ability and using more external sources of finance in their follow-up development stage especially that of their international operation can the development speed of small and medium-sized enterprises overcome the restriction of their own structure of raised capital and gain international advantages.

\section{III - To build omni-directional and multi-level financial support system for small and medium-sized enterprises}

A . To perfect financing guarantee system for small and medium-sized enterprises

Government functions should be fully elaborated, in the meanwhile leverage should be strengthened, and hence to the development of credit guarantee of small and medium-sized enterprises should be improved. The practice credit guarantee system for small and medium-sized enterprises pilot indicates that what credit guarantee realizes is its own economic efficiency, but it is more important to embody the comprehensive benefits of expanding employment, cultivating tax sources, booming the economy and stabilizing society. The government support promotes the development of it, which embodies this social function of credit guarantee. At the same time, credit guarantee has a function of magnifying leverage. Compared with other fiscal fund payment modes, such as subsidy, tax free, allocation and allowance, it can meet more social demand with less financial investment and has amplification efficiency of boosting the economic development with fiscal capital.

Meanwhile, the government is the main body of the enterprise tax. Government-funded credit guarantee institutions support the development of small and mediumsized enterprises by means of lever effect of guarantee, while the development of small and medium-sized enterprises in turn expands the tax sources and the government is one of the main beneficiaries. Moreover, under strict system construction and standard operation and from international experiences, the risk of small and medium-sized credit guarantee institutions is tolerable. Therefore, the government guarantee agencies should fully recognize the importance of credit guarantee of small and medium-sized enterprises and actively support the development of guarantee industry. The government should take out certain financial fund for capital injection and compensation every year.

The relationship between financial institution and credit guaranty should be handled correctly. The mechanism of guarantee agencies and financial institutions sharing the responsibility doesn't happen overnight. A good social environment needs to be cultivated. It also needs the vigorous support and the strong push of the government relevant laws, regulations and policies. A mechanism to spread the risk of guarantee organizations needs to be established to guarantee the long-time and stable development and functions display of guarantee organizations instead of solving problems only by the business contacts and negotiations between guarantee organizations and state-owned financial institutions.

Of course, the changes of bank concepts are also very important. The banks must consider the security of cooperation with guarantee organizations and asset with thinking of commercialization. Especially our country has joined the WTO, and the competition in the financial field becomes more and more fierce. Financial institutions should timely make further changes to the format terms of banks according to the 
experience of foreign countries and the actual situation of our country. In the matter of guarantee organizations and banks risk-sharing, financial institutions should shoulder some risk responsibilities, as guarantee organizations should shoulder $70 \%-90 \%$, while the banks should shoulder $10 \%-30 \%$. In this way, it not only can enhance the sense of responsibility of both sides and effectively guard against and control credit risk of loan enterprises, but also can spread the risk responsibility of guarantee organizations to some extent, which is to the benefit of the prosperity and development of the guarantee industry.

Credit rating system should be established to ease the loan applying tension of small and medium-sized enterprises. For bank regulators, credit assets are an important part of bank assets. The bank regulators need to continuous understand and monitor the quality condition of credit assets. The prominent problems of "moral hazard" in the financing of small and medium-sized enterprises caused by information asymmetry can be advised by independent third party---credit rating organizations for small and medium-sized enterprises, which is convenient for bank regulators' specific supervision. For commercial banks, specialized credit rating organizations for small and medium-sized enterprises can objectively assess the management condition and accounting risk of small and medium-sized enterprises with its scale advantage and professional and technical advantages. The commercial banks take the result as a reference and combine the norm of lending with them. This not only can reduce the risk of the loan but also can improve the level of income.

For small and medium-sized enterprises, credit rating system can promote the enterprise operation and management, strengthen the consciousness of credit, and inform financial institutions or the society of credit rating to produce a certain pressure to the enterprise so that to encourage the enterprises to improve management activities for gaining good grades. Establishing credit rating system for small and medium-sized enterprises, the government should increase the operation rate of credit rating results, definitude the legal status of credit rating activities of small and medium-sized enterprises and enforce the credit rating results being the most widely used. Except bank loans, the government can regard the credit rating result as a reference index in the aspects, such as enterprise industrial and commercial annual inspector, favorable tax treatment and so on. These measures not only are conducive to the government to reduce administrative costs and improve the utilization rate of credit ratings but also can make small and medium-sized enterprises have to face up to their reputation images and standard their behaviors so as to boost the improvement of credit environment and the development of credit economy.

Trade associations should play an active role in the construction of the credit guarantee system for small and medium-sized enterprises. They should actively take part in the construction of the credit guarantee system, study, formulate, promote and regulate trade associations to carry out the supporting policies to the industry credit system construction, develop guidance and lead trade associations to do this work well. Trade associations can take part in the construction of credit guarantee system for small and medium-sized enterprises, assist the government departments to research and formulate credit guarantee standard, take part in credit rating of small and medium-sized enterprises and take charge of the specific clerical work. Positioned the tie between credit guarantee institutions and government departments, guarantee industry association assists the small and medium-sized enterprises to seek guarantee consulting, which facilitates small and medium-sized enterprises financing, expands the cooperation between guarantee organizations and financial sectors, eases the financing difficulties of small and mediumsized enterprises so as to promote the development of them.

\section{$B$. To enhance the supporting power from government}

At present, Chinese government has already had a certain economic strength to support small and medium-sized enterprises financing. With the macroeconomic regulation and control experience carried on for many years, the government satisfies the policy conditions to intervene the small and medium-sized enterprises financing. Other than expanding the support in the process of perfecting credit guarantee system for small and medium-sized enterprises, the government can strengthen the efforts in support of the small and medium-sized enterprises financing in the following aspects.

Special assisting funds should be founded or the government compensating lending banks to encourage the positivity of the banks to issue loans to small and mediumsized enterprises. Small enterprises loan risk compensation fund should be set up by the finance kit of provinces, cities and counties at all levels. And the government comes out to share the risk of lending to small enterprises moderately.

The fiscal support system of small and medium-sized enterprises financing should be perfected. The government should increase the power of fiscal subsidies as far as possible and make sure that the subsidies fall into place. As the addition of these politic funds, such as innovation fund of small and medium-sized enterprises, special funds for development of small and medium-sized enterprises and special allowance funds of small and medium-sized enterprises service system, the funds should be input increasingly year by year and the investment growth rate shouldn't be lower than that of the fiscal revenue. A batch of taxation preference policies which exactly benefit the small and medium-sized enterprises should be gradually established. The tax rate of small and mediumsized enterprises should be deceased and especially for the small and medium-sized enterprises enjoying great national support, their income tax rate should directly be decreased; value-added tax rate of small-scale taxpayers can also considered to be decreased and broader and longer tax preference should be given.

Projects supported by international market development funds should be established. Small enterprises can get support from the special funds of the government in some projects, such as overseas exhibitions, promote in the international market, management system certification, creation of enterprise web sites, product certification, advertising 
trademark registration, overseas bidding and so on.

The project of disaster relief loans should be established to correctively assist the private and non-agricultural disaster stricken small and medium-sized enterprises. After small and medium-sized enterprises suffering from disasters, they should apply for relief loans from local related departments and the credit limit should be actual loss minus all the insurance payment, refund and subsidies. The applied funds are mainly used in resetting or rebuilding the enterprise plant, machinery and machinery equipments damaged by disasters.

\section{Financing institutions should intensify efforts to support} the development of small and medium-sized enterprises

Financial policies conducive to the sustainable development of small and medium-sized enterprises should be put into practice. The financing institutions should be encouraged to improve financial services, such as increasing financial support for small and medium-sized enterprises,

The regulatory departments of financial industry and financing institutions should change their concepts and continuously innovate the financial service for small and medium-sized enterprises: central bank stimulates the commercial banks to increase the lending to small enterprises through policies of risk pricing and floating rates, brings in international experience to carry out the small loan companies pilots and tries out small micro lending. CBRC positively lead and encourage the various financial institutions to carry out rich financial products suit to the financing characteristics of the small and medium-sized enterprises. NDRC further improves the small and medium-sized enterprise financing policy environment in aspect of small enterprises loan risk classification, provision, verification of doubtful and bad debts, credit business guidance and construction of small enterprises risk compensation funds.

Commercial banks should continuously expand the market of small and medium-sized enterprises, set up credit departments, improve credit assessment methods and incentive mechanism, carry out the financial products innovation, raise the level of financial services and increase the credit proportion for small and medium-sized enterprises. Joint-stock banks and city commercial banks all takes small and mediumsized enterprises as their main customers to launch products of certificates of deposit financing, warehouse receipts pledge, intellectual property rights pledge loan and so on. They also support the rapid development of large numbers of growing small and medium-sized enterprises. The foreign banks who has just entered the Chinese market are actively striving for the clients of small and medium-sized enterprises and have widened the financing channels of them.

\section{IV . Conclusion}

As a whole, Chinese small and medium-sized enterprises are faced with serious financing difficulties. To the small and middle-sized enterprises, there are problems existing, such as small scale, big changes, high risk and weak self-discipline. To the banks, there are small and medium-sized enterprises financing difficulties because of the banks' seeking the maximum benefits. To the government, there are problems of weak efforts of support. To completely solve the problem of small and medium-sized enterprises financing difficulties, it is impossible to rely on unilateral power. Only under cooperative efforts of the enterprises, banks and government can the financing difficulties of small and medium-sized enterprises be relieved effectively.

\section{Reference}

[1] ZOU Gao-feng,ZHANG Wei and XIONG Xiong, Innovation in SMEs' Financing Based on Credit Community, China Soft Science, vol.1, pp. 135-142, 2013.

[2] WANG Jian-xiu1,LI Chang-hong and ZHANG Gai-zhi, China Soft Science, vol.3, pp. 181-186, 2012.

[3] LV Wen-dong,XIAO Yang and ZHAO Yang, Assessment of Credit Risks about Microcredit Companies'Small and Medium Corporate Clients, Scientific Decision Making, vol.8, pp. 17-46, 2012.

[4] Zeng Gang,Wan Zhi-hong, Sustainable Development of Microfinance Institutions:A Study Based On International Experience, Financial Theory \& Practice, vol.7, pp. 3-8, 2009.

[5] HU Mei and WANG Hong-bin, Study on Small and Medium-Sized Financial Institution:Empirical Analysis Based on the Development of Small Loan Company, On Economic Problems, vol.6, pp. 106-110, 2009.

[6] Peng Jiangpo, The Credit Guarantee System of Medium-and-small Enterprises Based on Mutual Guarantee, Journal of Financial Research, vol.2, pp. 75-82, 2008.

[7] XU Li-xing,WANG Xin and GUO Jing, Innovation of Financial Products of Banks for STI-SMEs:Based on an Investigation into 107 Financial Products of 22 Banks in Nanjing, China Soft Science, vol.1, pp. 59-66, 2011.

[8] GU Hai-feng, Study on the Inner Mechanism to the Formation of SMEs' Credit Guarantee Risk, The Theory and Practice of Finance and Economics, vol.28, pp. 8-11, 2007.

[9] WANG Xin-ping, The Countermeasure of Improvement of Financial Freedom of Chinese Small and Medium-Sized Enterprises:On Bridging the "Macmillon Gap", Journal of Yibin University, vol.12, pp. 63-67, 2012.

[10] ZOU Yi-zhong, Lending Rates of Inventory Impawn Financing Based on the EOQ Inventory Model, Journal of Yibin University, vol.11, pp. 48$51,2011$. 